\title{
Experimental Investigation of Flow and Mechanical Properties of Fibrofor Fiber Reinforced Self-Compacting Concrete
}

\author{
H. R. Arun Kumar ${ }^{1}$ and B. Shivakumaraswamy ${ }^{2}$ \\ ${ }^{1}$ Assistant Professor, Department of Civil Engineering, \\ East West Institute of Technology, Visvesvaraya Technological University, Bangalore, Karnataka, India \\ ${ }^{2}$ Professor \& Head, Department of Civil Engineering, \\ Dr. Ambedkar Institute of Technology, Visvesvaraya Technological University, Bangalore, Karnataka, India \\ E-Mail: arunkumarhr1989@gmail.com, swamyait1@yahoo.com
}

\begin{abstract}
Self Compacting Concrete is a material used in the construction that has excellent deformability in the fresh state and high resistance of segregation, and can be replaced and compacted under its self-weight without applying vibration which leads to substantial advantages related to better homogeneity, enhancement of working environment and improvement in the productivity by increasing the speed of construction. Concrete can be formulated with high compressive strength but always has lower tensile strength. Tensile strength and other properties of concrete can be enhanced by adding fibers due to which the workability of concrete mix reduces and in order to achieve the desired Workability super-plasticizers is added. In the present work the use of fibrofor fiber in the production of self-compacting concrete (SCC) has been studied to identify how fresh and hardened properties of SCC are affected by the addition of fibers. The fibrofor fiber of $19 \mathrm{~mm}$ standard length is incorporated into the SCC mixtures as $0.5 \mathrm{~kg} / \mathrm{m}^{3}, 1.0 \mathrm{~kg} / \mathrm{m}^{3}$, $1.5 \mathrm{~kg} / \mathrm{m}^{3}$ of concrete. Test on fresh SCC like slump Flow test, $T_{50}$, V-Funnel test, J-Ring slump test and L-Box test were performed for an understanding of flow of SCC and tests on hardened properties like flexural strength, compressive strength and split tensile strength have been conducted to identify the hardened properties of SCC produced with fibrofor fiber. A comparative study between plain concrete, SCC without fiber and SCC with fiber has been done. Mix design for M40 grade concrete has been done according to EFNARC guidelines. The results reveal that the use of fibro for fiber decreases the workability but increases the mechanical properties of SCC. The optimum volume fraction of fibrofor fiber is determined as $1 \mathrm{~kg} / \mathrm{m}^{3}$ considering the optimized flexural strength and split tensile strength based properties of SCC. Due to increase in strength properties of fiber reinforced SCC that can be used for pavement construction and various other structures such as buildings, water retaining structures, reservoir structures and tunnel etc. Keywords: Fibrofor Fiber, Self-Compacting Concrete, Fresh Properties, Mechanical Properties
\end{abstract}

\section{INTRODUCTION}

Concrete is a major building material used in construction across the world. It is extremely versatile and is used for construction of all types of structures. Inadequate homogeneity of the cast concrete due to poor compaction or segregation may dramatically lower the performance of mature concrete in situ. To ensure adequate compaction and facilitate placement of concrete in structure with the congested reinforcement and in restricted areas, selfcompacting concrete (SCC) has been developed.

\section{A. Self-Compacting Concrete}

Self-compacting concrete (SCC) has ushered in a revolution in concrete technology. Self-compacting concrete flows under its own weight and completely fills the forms without segregation or bleeding [1]. Self-compacting concrete(SCC) first developed by okamura in late 1980's in Japan to achieve durable concrete structures in the context of shortage of trained manpower for vibrating and compacting concrete. Self-compacting concrete (SCC) has become a perfect match to placement of concrete by pumping. This type of concrete is also ideal when ready-mix concrete trucks are used since there will be practically no waiting time for the trucks, the turnaround times will be shorter leading to greater productivity per truck.

\section{B. Benefits of Self Compacting Concrete}

SCC has proved beneficial economically because of the following features:

1. Faster construction

2. Elimination of compaction

3. Reduction in site man power

4. Better surface finishes

5. Easier placing

6. Improved durability

7. Greater freedom in design

8. Thinner and complicated section

9. Improved and safer working environment

10. Reduced noise level

11. Greater productivity per track in $\mathrm{RMC}$

By employing self-compacting concrete, the extra cost of chemical and mineral admixtures is compensated by the elimination of vibrating compaction and work done to level surface of the normal concrete. SCC can greatly improve construction system primarily based on conventional concrete requiring vibrating compaction. Vibration compaction, which can easily cause segregation, has been an obstacle to the rationalization of construction work. Ones 
this obstacle has been eliminated concrete construction could be rationalized and a new construction system including formwork reinforcement support and structural design could be developed.

\section{MATERIALS FOR SELF COMPACTING CONCRETE}

Self-Compacting Concrete consists of the same components as conventionally vibrated concrete, which are cement, aggregates, and water, in addition to chemical and mineral admixtures in different proportions.

A. Cement: Ordinary Portland cement of 53 grade is used. [8]

TABLE I PHySiCAL PROPERTIES OF CEMENT

\begin{tabular}{|c|l|c|c|c|}
\hline S. No & \multicolumn{1}{|c|}{ Test Conducted } & Results & Requirements as per IS : 12269-1987(RA 2004) & Remarks \\
\hline 1 & Normal Consistency & $27.2 \%$ & Not Specified & - \\
\hline 2 & Initial Setting Time & 169 minutes & Shall not be less than 30 minutes & Passes \\
\hline 3 & Final Setting Time & 348 minutes & Shall not be less than 600 minutes & Passes \\
\hline 4 & Fineness(by blaine's Permeability method ) & $344 \mathrm{~m} 2 / \mathrm{kg}$ & Shall not be less than $225 \mathrm{~m} 2 / \mathrm{kg}$ & Passes \\
\hline 5 & Soundness(ByLe-Chatlier's method) & $0.5 \mathrm{~mm}$ & Shall not be more than $10 \mathrm{~mm}$ & Passes \\
\hline
\end{tabular}

TABle II Chemical Properties Of CEMENT

\begin{tabular}{|c|c|c|c|}
\hline S. No & Test Conducted & Results (\%) & $\begin{array}{l}\text { Requirements as per IS : 12269-1987 } \\
\text { (RA 2004) }\end{array}$ \\
\hline 1 & Total loss on Ignition & 1.43 & Not more than $4 \%$ \\
\hline 2 & Insoluble residue ( $\%$ by mass) & 1.25 & Not more than $3 \%$ \\
\hline \multirow[t]{2}{*}{3} & $\begin{array}{l}\text { Ratio of \% lime to \% of Silica, } \\
\text { Alumina and iron Oxide, } \\
\text { When Calculated by the Formula : } \\
\mathrm{CaO}-0.7 \mathrm{SO} 3\end{array}$ & \multirow[t]{2}{*}{0.88} & \multirow[t]{2}{*}{ Not greater than 1.02 and not less than 0.8} \\
\hline & $2.8 * \mathrm{SiO} 2+1.2 * \mathrm{AL} 2 \mathrm{O} 3+0.65 * \mathrm{Fe} 2 \mathrm{O} 3$ & & \\
\hline 4 & Ratio of \% Alumina to Iron oxide & 1.4 & Not less than 0.66 \\
\hline 5 & Total Sulphur Content Calculated as & 2.08 & Not more than $2.5 \%$ for $\mathrm{C} 3 \mathrm{~A}<\_5 \%$ \\
\hline 6 & $\begin{array}{l}\text { Sulphuric an hydride (SO3) } \\
(\% \text { by mass })\end{array}$ & & Not more than $2.5 \%$ for $\mathrm{C} 3 \mathrm{~A}<\_5 \%$ \\
\hline 7 & Magnesia $(\mathrm{MgO}),(\%$ by Mass $)$ & 1.14 & Not more than $6 \%$ \\
\hline 8 & Tricalcium Aluminate (C3A) (\% by mass) & 8.12 & - \\
\hline
\end{tabular}

\section{B. Aggregates}

\section{Coarse Aggregates}

The maximum size is generally limited to $20 \mathrm{~mm}$. Aggregates of size $10 \mathrm{~mm}$ to $12 \mathrm{~mm}$ is desirable for structures having congested reinforcement. Wherever possible the size of aggregate higher than $20 \mathrm{~mm}$ could also be used. Well graded cubical or rounded aggregates are desirable. Aggregates should be of uniform quality with respect to shape and grading. Sieve Analysis of Coarse Aggregate $12.5 \mathrm{~mm}$. Quantity of Sample taken 10kg. [8].

TABLE III Sieve ANALysis Of COARSE Aggregate 12.5MM, QuANTITy OF SAMPLE TOOK 10KG

\begin{tabular}{|l|c|c|c|c|c|}
\hline \multirow{2}{*}{ IS Sieve Designation } & \multirow{2}{*}{ Quantity Retained (kg) } & \multicolumn{2}{|c|}{ Cumulative Percentage } & \multicolumn{2}{|c|}{ Requirements as per IS:383-2016 (Percentage Passing) } \\
\cline { 3 - 6 } & & Retained & Passing & Single size & Graded \\
\hline $20.0 \mathrm{~mm}$ & 0.0 & 0.0 & 100.0 & - & 100 \\
\hline $16.0 \mathrm{~mm}$ & 0.0 & 0.0 & 100.0 & 100 & - \\
\hline $12.5 \mathrm{~mm}$ & 0.10 & 1.0 & 99.0 & $85-100$ & $40-100$ \\
\hline $10.0 \mathrm{~mm}$ & 3.74 & 38.4 & 61.6 & $0-45$ & $0-10$ \\
\hline $4.75 \mathrm{~mm}$ & 6.05 & 98.9 & 1.1 & -85 & -10 \\
\hline Pan & 0.11 & 100.0 & 0.0 & - & - \\
\hline
\end{tabular}

\section{Fine Aggregates}

It can be natural or manufactured. The grading zone to which it confirms must be uniform throughout the work. The moisture content or absorption characteristics must be closely monitored as quality of SCC will be sensitive to such changes [8]. 
Table Iv Test Result Of Fine Aggregate-Manufactured Sand As Per (Is 383-1970)

\begin{tabular}{|c|c|c|c|c|c|c|}
\hline \multirow[b]{2}{*}{ Sieve Designation in $\mathbf{m m}$} & \multirow[b]{2}{*}{ Quantity retained $(\mathrm{kg})$} & \multicolumn{2}{|c|}{$\mathrm{Cum} \%$} & \multicolumn{3}{|c|}{ Requirement as per IS :383-2016 } \\
\hline & & Ret & Passing & Zone 1 & Zone 2 & $\begin{array}{c}\text { Zone } \\
3\end{array}$ \\
\hline 10 & & 0.0 & 100.0 & 100 & 100 & 100 \\
\hline 4.75 & & 0.5 & 99.5 & $90-100$ & $90-100$ & $90-100$ \\
\hline 2.36 & & 17.1 & 82.9 & $75-100$ & $75-100$ & $75-100$ \\
\hline 1.18 & & 38.0 & 62.0 & $55-90$ & $75-100$ & $85-100$ \\
\hline 600 micron & & 50.8 & 49.2 & $30-70$ & $55-90$ & $75-100$ \\
\hline 300 & & 65.8 & 34.5 & $15-34$ & $35-59$ & $60-79$ \\
\hline 150 & & 80.2 & 19.8 & $5-20$ & $8-30$ & $12-40$ \\
\hline Pan & & 100 & 0.0 & - & - & - \\
\hline \multicolumn{7}{|c|}{ Fine aggregate (Manufactured Sand ) Conforms to Zone-2 as per IS383-1970 } \\
\hline
\end{tabular}

\section{Water}

Potable water can be used for manufacturing concrete. Water requirement must be established on the same line as that for using reinforced concrete or pre stressed concrete.

\section{Fibro-For Fiber}

Fibrofor Fiber is a revolutionary product which was introduced by BruggContec, Swiss Company which has a positive engineering history from last 30 years. They have also developed numerous fibres over the years most prominent types are Fibrofor fibres and Concrix fibres. The industrial process of manufacturing fibres takes place in very sophisticated and advanced plant which is approved by European Standards for building materials.

Fibrofor fiber is a microfibers or High performance fiber which is bundled, fibrillated construction with $3 \mathrm{D}$ fiber net aids in guaranteeing fast and constant spreading \& linking of concrete and fiber through the concrete mass.It mainly consists of Macro Polypropylene Fiber.In order to overcome the inherent drawbacks of ordinary concrete, such as low tensile strength, low deformation capacity, and poor postcracking ductility etc., fibers are introduced and widely used in the field of concrete engineering. It is commonly acknowledged that the addition of fiber into concrete matrix reduces the workability of concrete [2] and can enhance the tensile, flexural and impact strengths, toughness and post cracking ductility of concrete materials, and consequently improve the static, seismic and fatigue performance of concrete structures [3, 4]. Fibrofor fibers were added with three volume fraction, $0.5 \%, 1 \%$ and $1.5 \%[5,6]$.

Types of fibrofor fibre:

1. Fibrofor high grade.

2. Fibrofor diamond.

3. Fibrofor multi.

a. Product Description: High Grade is an upgraded, bundled, fibrillated high performance fiber serving as a structural concrete reinforcement. Particularly rough surface ensures efficient anchoring inside the concrete and guarantees fast three-dimensional distribution throughout the matrix during the mixing process. The enhanced technical parameters of the concrete can be used for structural design purposes. High Grade serves has a structural reinforcement, increases the impact resistance of the concrete and can be used in structural applications. High Grade prevents sedimentation - the subsequent settlement of the matrix.

High Grade creates a high level of resistance of concrete structures expose to aggressive waters. This significantly improves shrinkage and temperature crack control in tunneling and mining, residential and marine structures. It finds wide application in tunneling and mining, residential and marine structures. The main advantage of using the product is to reduce carbon footprint, explosive spalling, plastic settlement and permeability. It increases fatigue resistance, energy absorption and tensile strength.Smart Fiber Macro Synthetic Fiber is designed to perform in stringent conditions with the benefits of increased performance. Perfect bee-hive profile and three dimensional construction provides better reinforcements, reduced cost by replacing heavier steel mesh and improved safety conditions. It enhances the toughness of the Concrete without losing flexibility, thus, providing for better strength and well finished concrete surface. The product is extruded from virgin Polypropylene. Polypropylene is one of the most suitable raw materials being a stable yet, least reacting and tough material. The profiled three dimensional constructions provide good bonding between concrete and fiber.

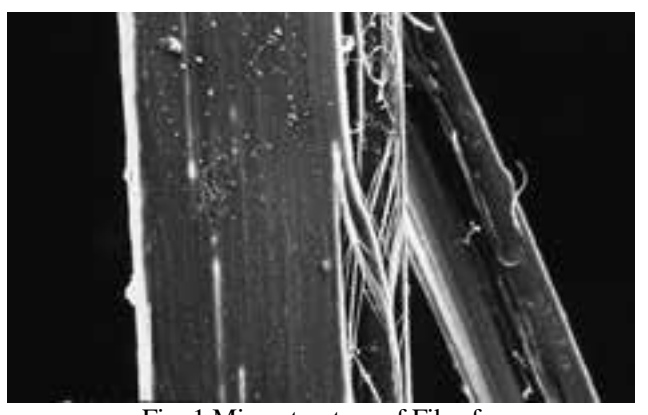

Fig. 1 Microstructure of Fibrofor 


\section{b. Features}

1. Well furnished.

2. Rugged structure.

3. Can withstand all weather conditions.

\section{c. Benefits of Using}

1. Significantly improves shrinkage and temperature crack control.

2. Safer and lighter to handle than steel.

3. Reduces carbon footprint.

4. Reduces explosive spalling.

5. Reduces plastic settlement.

6. Reduces permeability.

7. Unlike steel, doesn't stain concrete with rust marks.

8. Potential for increase in joint spacing.

9. Increases flexural strength.

10. Increases impact resistant.

11. Increases residual strength.

12. Increases fatigue resistance.

13. Increases tensile strength.

14. Increases energy absorption.

15. Increases ductility.

16. Increases toughness.

17. Increases post crack load capacity.

\section{d. Specifications}

1. Fibre Tuff is manufactured by Bajaj Reinforcements with high modulus between $6 \mathrm{Gpa}$ to $10 \mathrm{Gpa}$.

2. Continually embossed surface anchorage mechanism to enhance bond

3. Fibre Tuff Macro Structural Synthetic Fibres conforms to classification BS EN. 14889 - 2, under class II: Macro Fibres: $>0.30 \mathrm{~mm}$ in diameter.

4. Tensile strength between $550 \mathrm{Mpa}$ to $640 \mathrm{Mpa}$ and in lengths $36 \mathrm{~mm} / 47 \mathrm{~mm} / 54 \mathrm{~mm} / 60 \mathrm{~mm}$.

TABLE V Physical PROPERTIES Fibrofor Fibre

\begin{tabular}{|l|c|}
\hline \multicolumn{1}{|c|}{ Form } & Fibrillated \\
\hline Bulk density & 0.91 \\
\hline Lengths & $\begin{array}{c}19 \mathrm{~mm} \text {,tolerance }+/-1.5 \mathrm{~mm} \\
38 \mathrm{~mm} \text {,tolerance }+/-5 \%\end{array}$ \\
\hline Colour & Beige \\
\hline Resistance to acids/alkalis & Inert \\
\hline Tensile strength & $400 \mathrm{~N} / \mathrm{mm}^{2}$ \\
\hline Modulus of Elasticity & $4900 \mathrm{~N} / \mathrm{mm}^{2}$ \\
\hline Softening point & $1500 \mathrm{C}$ \\
\hline Foil thickness & $80 \mathrm{micro} \mathrm{meter}$ \\
\hline
\end{tabular}

\section{E. Super Plasticizers}

Polycarboxylic ether based super plasticizers is tested for Uniformity as per IS 9103-1999. The results are given in following table. Admixture is defined as a material, other than cement, water and aggregate. This is used as ingredient of concrete and is added to the batch immediately before or during mixing.

\section{Chemical Admixtures}

Super Plasticizers: Super Plasticizers is an essential Component of SCC to provide the necessary Workability. Super Plasticizers are available in three types generally, in local market namely,

a. Melamine based Super Plasticizers,

b. Napthalene based Super Plasticizers

c. Poly-Carboxylate Ether (PCE) based Super Plasticizers.

Poly-Carboxylic ether based Super Plasticizers (Glenium B233) was used in this study [3]. Whose Properties are shown below.

TABLE Vi PROPERTIES Of GLENIUM B-233

\begin{tabular}{|c|l|c|}
\hline $\begin{array}{c}\text { S. } \\
\text { No. }\end{array}$ & \multicolumn{1}{|c|}{ Particulars } & $\begin{array}{c}\text { Value/Description (as per } \\
\text { manufacturer) }\end{array}$ \\
\hline 1 & Form & Liquid \\
\hline 2 & Color & Light Brown \\
\hline 3 & Specific Gravity & 1.2 \\
\hline 4 & $\begin{array}{l}\text { Viscosity (25 degree } \\
\text { centigrade) }\end{array}$ & $150 \mathrm{cps}$ \\
\hline 5 & $\mathrm{pH}$ & $6-9$ \\
\hline 6 & Chloride Content & $<0.2 \%$ \\
\hline
\end{tabular}

Newly developed types of Super Plasticizers, Known as Poly-carboxylated ethers (PCEs), are particularly relevant and most effective to produce SCC. They reconcile the apparently conflicting requirements of flow and cohesion, avoiding Potential Problems with unwanted retardation and Excessive air entrainment (generally caused due to overloading), Particularly at Higher Workability. Viscosity Modifying admixtures can also with Super Plasticizers to make the Concrete mix Viscous.

\section{F. Marsh Cone Test}

The marsh cone test is a simple approach to get some data about cement Pastes rheological behavior, it has been already used in cement based materials mix design in order to define the Super plasticizer saturation point, i.e.; the dosage beyond which the flow time do not decrease appreciably. Marsh Cone test is easy to Perform and seems to give better results. The test assembly is portable making it handy at the site. It also requires small quantity of materials. In marsh Cone, Cement slurry is prepared and its flow ability is checked. Where in Concrete, it is the Cement Paste that influences the flow ability. It is observed that a paste reheology model is useful to the SCC mix design. Although, the quantity of aggregate, its shape and texture etc., will make the test more complex and often erratic. The use of a paste alone will make the test simple, consistent and indicative of the fluidity effect of super plasticizers with the Cement. The optimum dosage of super plasticizers is $8 \mathrm{ml} / \mathrm{kg}$ of cement content for $1.0 \mathrm{~kg} / \mathrm{m} 3$ fiber and the amount of super plasticizer varied for different fiber dosages. 


\section{G. Mix Design of Self Compacting Concrete}

The mix design of self -compacting concrete is given in the following table: Ref Table IV.

1. $\quad$ Specific gravity of Cement $=3.15$.

2. Specific gravity of Sand $=2.67$.

3. Specific gravity of Coarse aggregate $=2.65$

TABle ViI Total QuantiTy OF MATERIALs For Mix

\begin{tabular}{|l|c|c|}
\hline \multicolumn{1}{|c|}{ Material } & By Volume in Liters' & By wt in kg \\
\hline Cement & 120.1 & 350 \\
\hline Water & 140 & 8.5 \\
\hline Admixtures & 0.18 & 180 \\
\hline Fine Aggregates & 429 & 1145 \\
\hline Coarse aggregate 12mm & 286 litres & $757.9 \mathrm{~kg}$ \\
\hline Fibrofor Fibre & - & $1.5 \mathrm{~kg} / \mathrm{m} 3$ \\
\hline Total & 986.29 litres & $2261.58 \mathrm{~kg}$ \\
\hline
\end{tabular}

The mix design is done based on EFNARC guidelines. We optimize the flow and stability of the paste. The next step is to determine the required amount of fiber to be added for required structural feasibility. Finally, the production of freshly prepared SCC was done in a mixer, and then the required tests were performed.

\section{EXPERIMENTAL INVESTIGATION}

Tests to be fulfilled to qualify as SCC:

Though there are many test methods to confirm the qualification to SCC, as mentioned above, no single method of combination of methods have obtained universal acceptance. One cannot declare a mix of SCC by only looking at the slump flow. For example, a mix with slump of even $650 \mathrm{~mm}$ or more may not be SCC, as it may, sometimes be susceptible to blocking and segregation as well. For example, in Japan, the slump flow test, V-funnel

test, and the box shaped test (or U-box test) are used for the purpose of SCC acceptance. In Sweden slump flow and Lbox test are used. Hence, any mix aimed to be SCC must be tested for at least three workability tests. These can be a combination of any of the following, in addition to slump flow test, V-funnel test, L-box blocking ratio test etc.

TABLE VIII ACCEPTANCE CRITERIA FOR SCC

\begin{tabular}{|c|c|c|c|c|}
\hline \multirow{2}{*}{ S. No } & \multirow{2}{*}{ Method } & \multirow{2}{*}{ Unit } & \multicolumn{2}{|c|}{ Typical range of values } \\
\hline & & & Minimum & Maximum \\
\hline 1 & $\begin{array}{l}\text { Slump flow } \\
\text { by Abrams } \\
\text { cone }\end{array}$ & $\mathrm{Mm}$ & 650 & 800 \\
\hline 2 & $\begin{array}{l}\mathrm{T}_{50} \mathrm{~cm} \text { slump } \\
\text { flow }\end{array}$ & $\mathrm{Sec}$ & 2 & 5 \\
\hline 3 & $\mathrm{~J}$-ring & $\mathrm{Mm}$ & 0 & 10 \\
\hline 4 & V-funnel & $\mathrm{Sec}$ & 6 & 12 \\
\hline 5 & $\begin{array}{l}\mathrm{V} \text {-funnel at } \mathrm{T} \\
\text { 5minutes }\end{array}$ & $\mathrm{Sec}$ & 0 & +3 \\
\hline 6 & L-box & $\mathrm{h} 2 / \mathrm{h} 1$ & 0.8 & 1.0 \\
\hline 7 & U-box & h2-h1 & 0 & 30 \\
\hline 8 & Fill-box & $\%$ & 90 & 100 \\
\hline 9 & $\begin{array}{l}\text { GTM screen } \\
\text { stability test }\end{array}$ & $\%$ & 0 & 15 \\
\hline 10 & Orimet & $\mathrm{Sec}$ & 0 & 5 \\
\hline
\end{tabular}

\section{A. Flow and Mechanical Properties Test}

The tests are to be performed by having a variation of the percentages of fibers used and the type of fibers used: Slump Flow Test, V-Funnel time in sec, T50 time in sec, J-Ring slump in $\mathrm{mm}$, J-Ring $\mathrm{H}$ in $\mathrm{mm}$, L-Box $\mathrm{H}$ ratiofor determining flow properties [7] and compressive strength test, Flexure Strength test and Split tensile strength test were carried out to determine the mechanical properties.

\section{RESULTS AND DISCUSSIONS}

\section{A. Flow Properties Test Results}

TABLE IX Flow PROPERTIES With AND WiTHOUT FIBERS

\begin{tabular}{|c|c|c|c|c|c|c|}
\hline $\begin{array}{c}\text { Mixes with Fibro } \\
\text { For Fibre }\end{array}$ & $\begin{array}{c}\text { Slump Flow } \\
\text { in } \mathbf{~ m m ~}\end{array}$ & $\begin{array}{c}\mathbf{T}_{50} \text { cm time in } \\
\text { sec }\end{array}$ & $\begin{array}{c}\text { V-Funnel time in } \\
\text { sec }\end{array}$ & $\begin{array}{c}\text { J-Ring slump } \\
\text { in } \mathbf{~ m m ~}\end{array}$ & $\begin{array}{c}\text { J-Ring ' } \mathbf{H} \text { ' } \\
\text { in } \mathbf{~ m m}\end{array}$ & L-Box H ratio \\
\hline SCC & 720 & 2.5 & 9 & 620 & 3 & 0.76 \\
\hline Mix $1-0.5 \mathrm{Kg} / \mathrm{m} 3$ & 670 & 4.5 & 11.3 & 610 & 6 & 0.78 \\
\hline Mix2-1.0Kg/m3 & 660 & 4.8 & 11.7 & 590 & 8 & 0.86 \\
\hline Mix $3-1.5 \mathrm{Kg} / \mathrm{m} 3$ & 640 & 5.2 & 12.1 & 570 & 10 & 0.92 \\
\hline EFNARC Min. & 650 & 2 & 8 & & 0 & 0.8 \\
\hline EFNARC Max. & 800 & 5 & 12 & & 10 & 1 \\
\hline
\end{tabular}

\section{Slump Flow Test}

The slump flow test is used to assess the horizontal free flow without presence of obstructions. This method is based on determining the slump and the indicators: Diameter of the concrete circle and T500 sec (time taken from the initial flow to the flow of concrete at $500 \mathrm{~mm}$ diameter) gives the measure of the filling ability and the viscosity of the concrete. 


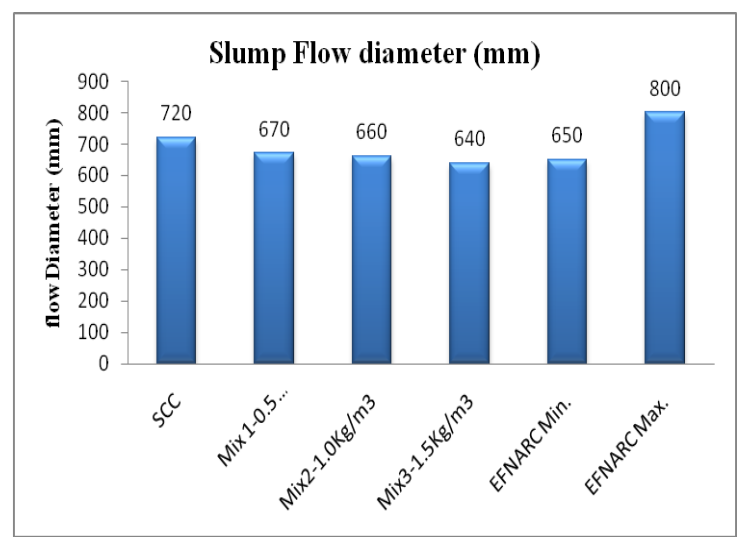

Fig. 2 Graphical representation of Slump Flow Diameter for various mixes

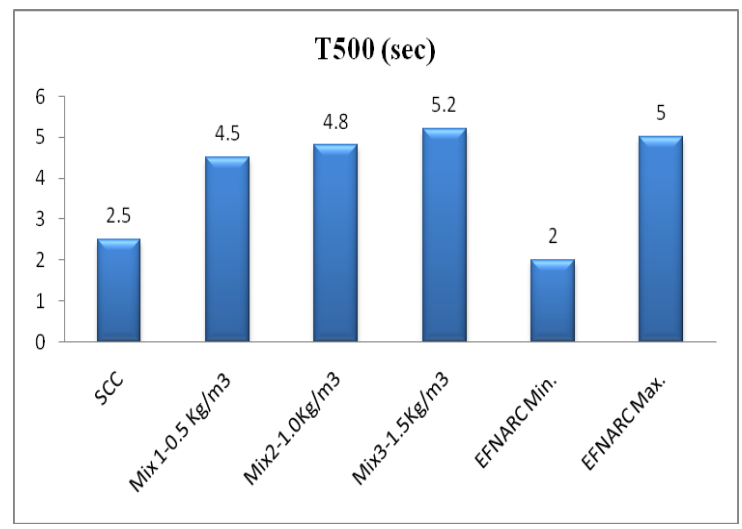

Fig. 3Graphical Representation of T500 of Various Mixes

The higher the slump flow (SF) value, the greater its ability to fill formwork under its own weight. A value of at least $650 \mathrm{~mm}$ is required for SCC. In case of severe segregation more amount of coarse aggregate will remain in the centre of the pool of concrete and mortar and cement paste at the concrete periphery.

In case of minor segregation, a border of mortar without coarse aggregate can occur at the edge of the pool of concrete. If none of these phenomena appear it is no assurance that segregation will not occur since this is a time related aspect that can occur after a longer period.

\section{J-Ring Test}

It's the measure of the ability of concrete to flow or the passing ability through obstruction and reinforcement places. The slump flow apparatus is used along with J-ring for the above purpose. The test is used as a quality control test in the field. The cone is kept at the center of the flow table along with the J-Ring and is filled with concrete.

The concrete is then released to allow the concrete to flow. The main superiority of the test is that it accounts for the obstruction by considering bars of the J-Ring through which the concrete flows and as result, it gives a difference in height of the concrete as it passes through the gaps and finally the flow stops.

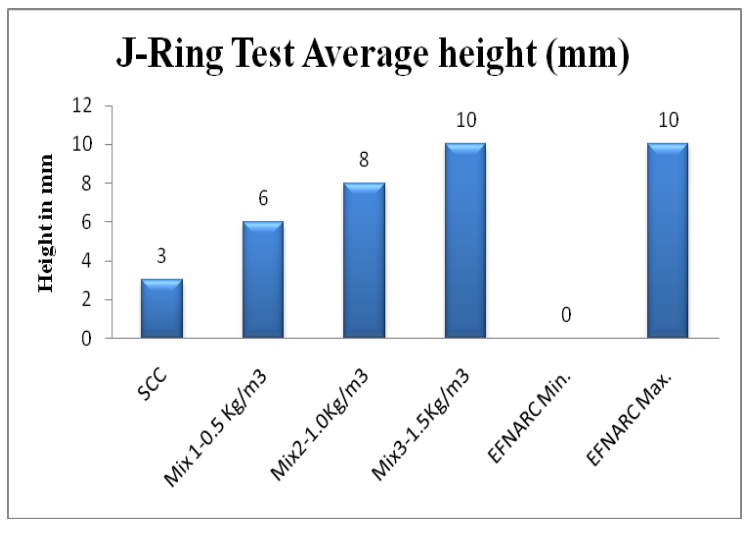

Fig. 4 Graphical representation of J-Ring height for various mixes

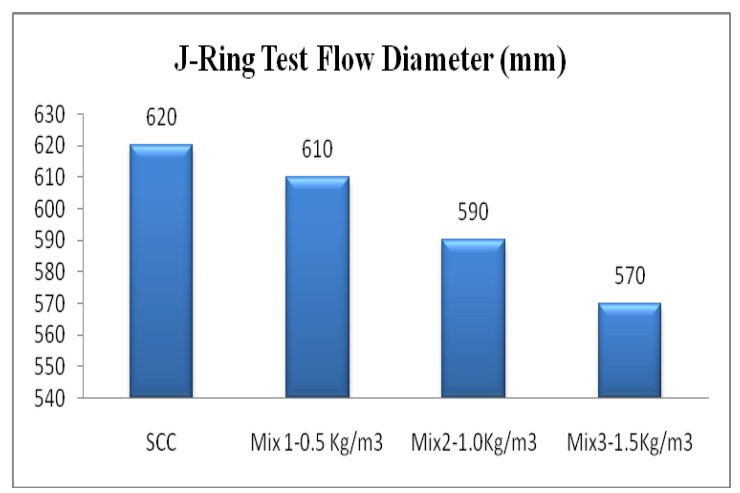

Fig. 5 Graphical representation of J-Ring Flow Diameter for various mixes

The measured flow is certainly affected by the degree to which the concrete movement is blocked by the reinforcing bars. The extent of blocking is much less affected by the flow characteristics, and we can say that clearly, the greater the difference in height, the lesser is the passing ability of the concrete.

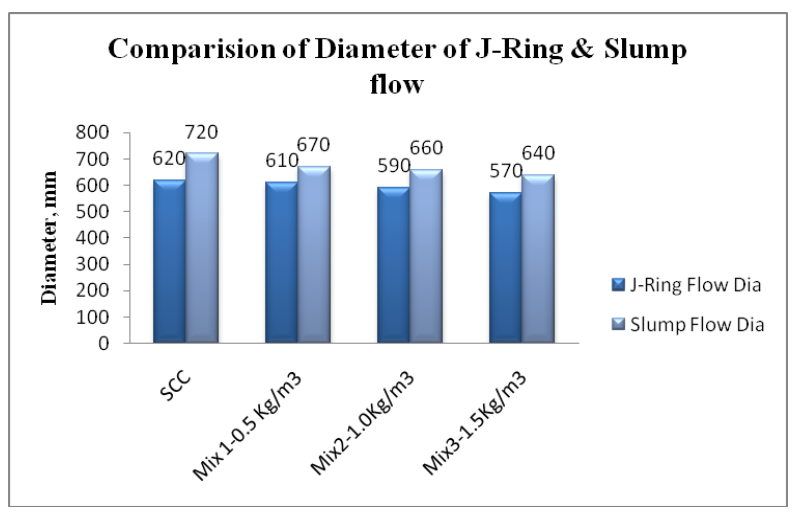

Fig. 6 Comparison of Diameter of J-ring and Slump Flow

Similar results have been obtained in the J-ring test when compared with Slump Flow but there has been a decrease in the values of all mixes due to the presence of reinforced steel bars in the J-ring that obstructs the flow and increases the viscosity of the concrete. The results show that the Jring test gives a total quality control and is a better field test for assessing the workability of concrete as it considers all the parameters of passing ability. 


\section{V Funnel Test}

$\mathrm{V}$-funnel test is used to determine the filling ability (flow ability) of the concrete with a maximum aggregate size of $20 \mathrm{~mm}$; in this study $12 \mathrm{~mm}$ size aggregate has been used. The funnel is filled with about 12 liter of concrete and the time taken to flow through the apparatus is measured. Later, the funnel is refilled with concrete and left for 5 minutes to settle. If the concrete shows segregation then the flow time will get increased significantly.

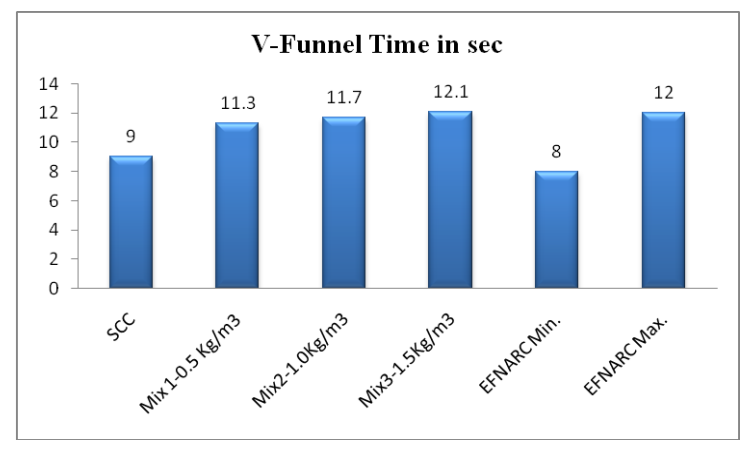

Fig.7 Graphical Representation of V-Funnel time (sec) of Various Mixes

This test measures the ease of flow of concrete, shorter flow time indicates greater flow ability. For SCC a flow time of 10 seconds is considered appropriate. The inverted cone shape restricts the flow, and prolonged flow times may give some indication of the susceptibility of the mix to blocking.

\section{L-Box Test Method}

The apparatus consists of a rectangular-section box in the shape of an ' $\mathrm{L}$ ', with a vertical and horizontal section, separated by a moveable gate, in front of which vertical lengths of reinforcement bar are fitted. The vertical section is filled with concrete, and then the gate lifted to let the concrete flow into the horizontal section. When the flow has stopped, the height of the concrete at the end of the horizontal section is expressed as a proportion of that remaining in the vertical section $(\mathrm{H} 2 / \mathrm{H} 1$ in the diagram). It indicates the slope of the concrete when at rest. This is an indication passing ability, or the degree to which the passage of concrete through the bars is restricted.

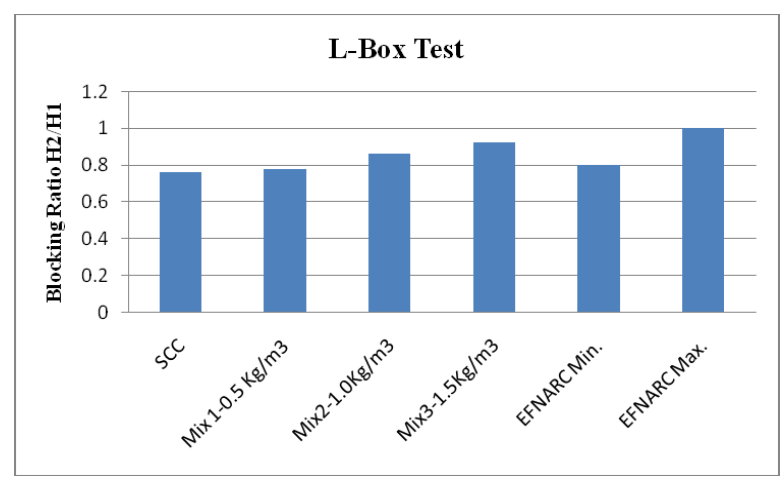

Fig. 8 Graphical Representation of L-Box Text of Various Mixes
If the concrete flows as freely as water, at rest it will be horizontal, so $\mathrm{H} 2 / \mathrm{H} 1=1$. Therefore, the nearer this test value, the 'blocking ratio', is to unity, the better the flow of the concrete. The EU research team suggested a minimum acceptable value of 0.8 .

\section{MECHANICAL PROPERTIES TEST RESULTS}

The mechanical properties such as Compressive strength test, split tensile strength test and flexural strength test were conducted and results are discussed. The compressive strength, split tensile strength and flexural strength specimens were tested after 7 and 28 days, the average strengths of the three specimens were computed and presented in the results.

\section{A. Compressive Strength Test}

The Compressive strength test on conventional concrete (CC), SCC without Fibrofor fibre (FF) and SCC with Fibrofor fibre of different dosages for 7 days at 28 days were conduced.

The compressive test specimens were of dimensions 150x150x150mm. Conventional Concrete, SCC with and without Fibrofor fiber was compared and SCC with fiber shows slight decrease in compressive strength. SCC decreases $10.67 \%$, Mix-1 decreases by $13.15 \%$, Mix-2 decreases by $13.44 \%$ and Mix-3 decreases by $18.4 \%$ when compared to conventional concrete (28days strength) as shown in table $\mathrm{X}$.

TABLE X COMPRESSIVE STRENGTH IN N/MM² OF DifFERENT CONCRETE MIXES

\begin{tabular}{|l|c|c|}
\hline \multicolumn{3}{|c|}{ Compressive Strength $\mathbf{N} / \mathbf{m m}^{\mathbf{2}}$} \\
\hline & 7 Days & 28 Days \\
\hline CC & 32.86 & 49.8 \\
\hline SCC & 29.07 & 45 \\
\hline Mix $1-0.5 \mathrm{Kg} / \mathrm{m} 3$ & 29.04 & 44.01 \\
\hline Mix2-1.0Kg/m3 & 28.97 & 43.9 \\
\hline Mix3-1.5Kg/m3 & 27.7 & 42.07 \\
\hline
\end{tabular}

\section{B. Split Tensile Strength}

The test is performed for tensile strength in which specimen is taken in a cylindrical form and is loaded for failure by compression along the diameter and is applied along the entire length. In the Split Tensile Strength, the strength gets influenced by the dosage of fibers.

In the Figure, it can be interpreted that the split tensile strength increases i.e. the tensile character increases with the increase in fiber dosage. The optimum dosage of Fibrofor Fiber reinforced SCC is $1-\mathrm{kg} / \mathrm{m}^{3}$ which shows $8.68 \%$ increased in strength compared to $\mathrm{CC}$ and $7.46 \%$ increased when compared to SCC (28 Days strength). 
TABLE Xi SPlit TENSILE STRENGTH In N/MM² Of DifFERENT CONCRETE MIXES

\begin{tabular}{|l|c|c|}
\hline \multicolumn{3}{|c|}{ Split Tensile Strength N/mm } \\
\hline & 7 Days & 28 Days \\
\hline CC & 1.749 & 2.65 \\
\hline SCC & 1.756 & 2.68 \\
\hline Mix $1-0.5 \mathrm{Kg} / \mathrm{m} 3$ & 1.78 & 2.7 \\
\hline Mix2-1.0Kg/m3 & 1.9 & 2.88 \\
\hline Mix3-1.5Kg/m3 & 1.82 & 2.76 \\
\hline
\end{tabular}

\section{Flexural Strength}

Flexural strength, also known as modulus of rupture, or bend strength, or transverse rupture strength is a property specific of a material, it's the stress at which a material yield in a flexure experiment. In the Flexure strength test, the strength is affected due to the change in fiber dosage. According to the Table XI and Table XII, by increasing the fiber dosage, the flexural strength increases. The optimum dosage of Fibrofor Fiber reinforced SCC is $1-\mathrm{kg} / \mathrm{m}^{3}$ which shows $8.96 \%$ increased in strength compared to CC and $2.69 \%$ increased compared to SCC (28 Days strength).

TAble XiI FleXural Strength In N/MM² Of DifFERENT Concrete MIXES

\begin{tabular}{|l|c|c|}
\hline \multicolumn{3}{|c|}{ Flexural Strength N/mm } \\
\hline & 7 Days & 28 Days \\
\hline CC & 3.24 & 4.91 \\
\hline SCC & 3.36 & 5.21 \\
\hline Mix $1-0.5 \mathrm{Kg} / \mathrm{m} 3$ & 3.38 & 5.24 \\
\hline Mix2-1.0Kg/m3 & 3.53 & 5.35 \\
\hline Mix3-1.5Kg/m3 & 3.5 & 5.25 \\
\hline
\end{tabular}

\section{CONCLUSION}

1. From the present studyFibrofor fibre reinforced selfcompacting concrete were developed. In the fresh state, as the addition of fibre increased it caused lower flowability, passing ability and segregation resistance and hence the super plasticizer dosage was increased from $0.7 \%$ to $0.9 \%$ as the fibre content increased from 0 to $1.5 \mathrm{~kg} / \mathrm{m}^{3}$. The super plasticizer dosage for fibre content greater than $1.5 \mathrm{~kg} / \mathrm{m}^{3}$ was more than $0.8 \%$ which caused bleeding and segregation. So it can be concluded that beyond $1.5 \mathrm{~kg} / \mathrm{m}^{3}$ fibre content it is difficult to achieve Fibrofor fibre reinforced selfcompacting concrete.

2. From the results of hardened properties it is found that the compressive strength reduces as the percentage of fibres increases. Fig (9).

3. The highest value for the split tensile strength (2.88Mpa) is obtained from the concrete mixture incorporated with the content of $1 \mathrm{~kg} / \mathrm{m} 3$ fiber having the length of $19 \mathrm{~mm}$ (standard length) which indicated an increase in the split tensile strength value by about $8.68 \%$ Fig (10), compared to the controlled concrete (28 days).

4. The highest value for the flexural strength $(5.35 \mathrm{Mpa})$ is obtained from the concrete mixture incorporated with the content of $1 \mathrm{~kg} / \mathrm{m} 3$ fiber having the length of $19 \mathrm{~mm}$ (standard length)which indicated an increase in the flexural strength value by about $8.96 \%$ Fig (10), compared to the controlled concrete ( 28 days).

5. Higher value for the split tensile strength and flexural strength of fiber reinforced SCC is achieved for $1.0 \mathrm{~kg} / \mathrm{m}^{3}$ addition of fibres and hence it is considered as an optimum dosage from strength parameters and it can be concluded that addition of Fibrofor fibre into SCC will improve the mechanical properties.

\section{REFERENCES}

[1] Bobby Ramteke, R.K.Parve, Anand Khangan, and Nikhil Bandwal, "Experimental study on flexural behavior of the self -compacting concrete with hybrid fibers", IJCIET, Vol. 6, No. 5, pp. 144-152, May 2015.

[2] Mustafa Sahmaran, Alperen Yurtseven, and I. Ozgur Yaman (2004), "Workability of hybrid fiber reinforced self -compacting concrete", Building and Environment, Vol. 40, pp. 1672-1677, 2005.

[3] Biao Li, Lihua Xu, Yuchuan Shi, Yin Chi, Qi Liu, and Changning Li. "Effects of fiber type, volume fraction and aspect ratio on the flexural and acoustic emission behaviors of steel fiber reinforced concrete", Construction and Building Materials, Vol. 181, pp. 474-486, 2018.

[4] Zeynep Algin, and Mustafa Ozen, "The properties of chopped basalt fiber reinforced self -compacting concrete", Construction and Building Materials, Vol. 181, pp. 678-685, 2018.

[5] Wasim Abbass, M. Iqbal Khan, and Shehab Mourad, "Evaluation of mechanical properties of steel fiber reinforced concrete with different strengths of concrete", Construction and Building Materials, Vol. 168, pp. 556-569, 2018.

[6] Malgorzata Pajak, and Tomasz Ponikiewski, "Experimental Investigation on hybrid steel fibers reinforced self -compacting concrete under flexure", Procedia Engineering, Vol. 193, pp. 218225, 2017.

[7] EFNARC 2005, Specification and guidelines for self-compacting concrete. EFNARC (European Federation of Producers and Applicators of Specialist /products of Structures)

[8] Indian standard code books: Requirements as per IS: 12269-1987 (RA 2004), Requirements as per IS: 383-2016 (Percentage Passing). 